\title{
Teaching and research on Developmental Biology in Portugal
}

\author{
SÓLVEIG THORSTEINSDÓTTIR*, GABRIELA RODRIGUES and EDUARDO G. CRESPO \\ Departamento de Biologia Animal e Centro de Biologia Ambiental, Faculdade de Ciências, \\ Universidade de Lisboa, Portugal
}

\begin{abstract}
Developmental Biology has established itself as a solid field of teaching and research in Portugal. Its history is recent, generally considered to have started with the pioneering work of Augusto Celestino da Costa at the beginning of the $20^{\text {th }}$ century. However, research groups were very few and, until the early 1990's, teaching beyond morphological and comparative embryology was uncommon. In 1994, the first university course dedicated to Developmental Biology as a separate field from Embryology was created at the Faculty of Sciences of the University of Lisbon and a course on Plant Differentiation and Morphogenesis was also initiated. A Masters programme in Developmental Biology followed at the Lusófona University in 1996. Subsequently, modules of Developmental Biology were included in many Embryology courses and eventually more Developmental Biology courses were created. From 1999 onwards, the number of research groups working in Developmental Biology started to increase, many of which were initiated by researchers who had had the opportunity to pursue their PhD and/or post-doc studies abroad. The Instituto Gulbenkian de Ciência (Gulbenkian Institute of Science) became the first home of most of these groups, but several later spread to other institutions. This increased activity in turn has stimulated teaching of Developmental Biology and more students have been getting interested in the field. This "positive feedback loop" makes it a nice time to be teaching and working in Developmental Biology in Portugal.
\end{abstract}

KEY WORDS: Developmental Biology, teaching, research, Portugal

\section{Teaching and research in Embryology in Portugal - the beginning}

The dawn of developmental biology in Portugal started with the work of Augusto Celestino da Costa (1884-1956), who, as a Professor in the Faculty of Medicine at the University of Lisbon, taught Embryology and Histology and set up a laboratory dedicated to the study of histology and comparative embryology (see David-Ferreira, 2009).

Celestino da Costa influenced many young students that passed through his laboratory. One of those was Xavier Morato (1906-1988) who became Celestino da Costa's successor at the Faculty of Medicine of the University of Lisbon and maintained the excellence of Embryology and Histology after Celestino da Costa's retirement. Xavier Morato trained yet another prominent histologist and cell biologist, José F. David-Ferreira, who would later have an important role in advancing developmental biology in Portugal (see below). Another of Celestino da Costa's disciples was the biologist Germano da Fonseca Sacarrão (1914-1992). Sacarrão worked with Celestino da Costa for a couple of years, and in 1942, with Celestino da Costa's support and a scholarship from the recently created Instituto de Alta Cultura (Institute for Higher Culture), Germano Sacarrão went abroad to work in the laboratory of the prominent marine zoologist Adolf Portmann (1897-1982) at the Zoologische Austalt in the University of Basel in Switzerland. It was under Portmann's supervision that Sacarrão started his research on the embryology of Cephalopods, which was to be the major subject of his research during his stay in Basel and after his return to Portugal (Fig. 1). In 1944, Germano Sacarrão got a position as a naturalist at the Museu Bocageat the Faculty of Sciences of the University of Lisbon. Apart from dedicating himself to the collections of the museum, he continued his work on the development of Cephalopods from a morphological and evolutionary perspective, rejecting to a certain extent the

\footnotetext{
Abbreviations used in this paper: IGC, Instituto Gulbenkian de Ciência (Gulbenkian Institute of Science); PGDBM, Programa Gulbenkian de Doutoramento em Biologia e Medicina (Gulbenkian PhD Programme in Biology and Medicine).
}

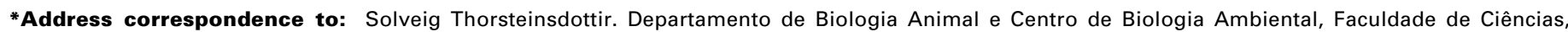
Universidade de Lisboa, 1749-016 Lisboa, Portugal. Fax: +351-217-500-028. e-mail: solveig@fc.ul.pt - web: http://cba.fc.ul.pt/development-group.aspx 
reductionist approach of the genetics of his time. He defended his PhD thesis "On the early phases of ontogeny of Tremoctopus violaceus" at the University of Lisbon in 1951 and started his career as a lecturer at the Faculty of Sciences that same year, becoming Full Professor of Zoology in 1960. He taught a variety of subjects within the area of biology and was an excellent teacher. Not only was he an extraordinarily knowledgeable person, but he managed to interconnect a variety of areas within biology and stressed the essence of an integrative approach to biological problems. His vast knowledge and scientific rigour, his enthusiasm, his informal way of dealing with students as well as his excellent sense of humour made Sacarrão a teacher to be remembered.

One of his students, Eduardo G. Crespo, became fascinated with this approach to biology. He finished his degree in Biology in 1964, did four years of military service in Mozambique, returned to Lisbon to teach for a year in high
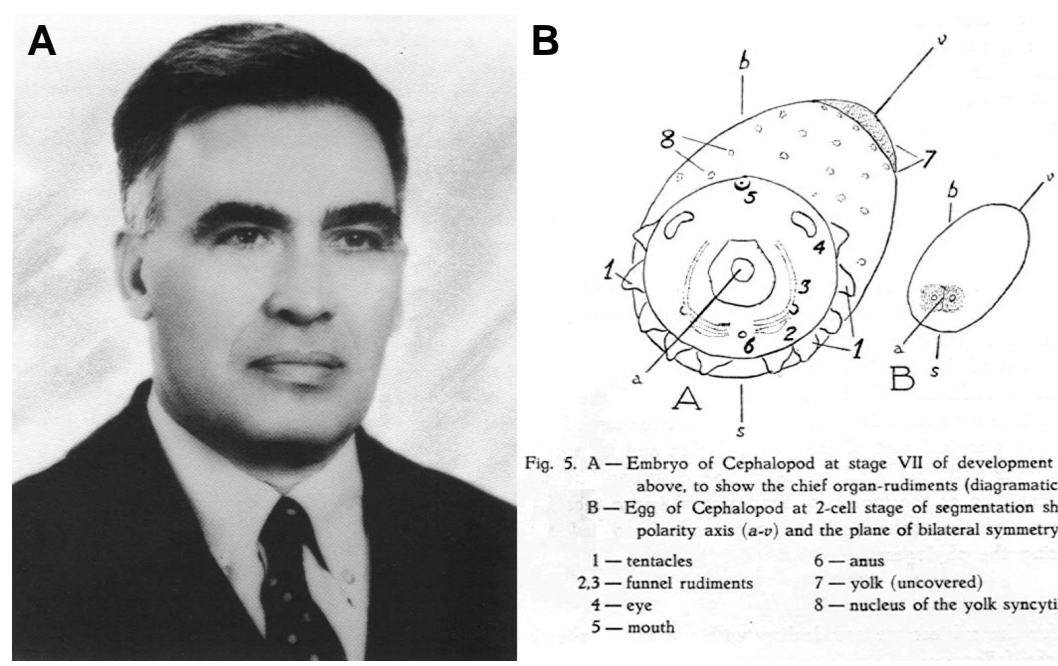

Fig. 5. A-Embryo of Cephalopod at stage VII of development seen from above, to show the chief organ-rudiments (diagramatic). B-Egg of Cephalopod at 2-cell stage of segmentation showing the polarity axis $(a-v)$ and the plane of bilateral symmetry $(b-s)$.

$\begin{array}{ll}2,3-\text { funnel rudiments } & 7-\text { anus } \\ \text {-yolk (uncovered) }\end{array}$

4 - eye 8 - nucleus of the yolk syncytium.

5 - mouth

Fig. 1 Germano da Fonseca Sacarrão. (A) Photo from 1970's. (B) A drawing from his work "On the position of the ontogeny of cephalopods in relation to the development of other molluscs". Separata da Revista da Faculdade de Ciências de Lisboa, $2^{a}$ série, C, Vol X:1-54, (1962)

school and was then hired as a teaching assistant by Germano Sacarrão in 1969. Eduardo G. Crespo taught a variety of subjects, and took the same integrative approach as Sacarrão both in his teaching and research. Although he did not dedicate his own research to embryology per se, his work on the biology of amphibians and reptiles always maintained an integrative approach addressing problems of biological diversity and adaptation through the eyes of an "early version" Evo-Devo researcher. Eduardo G. Crespo completed his PhD thesis at the University of Lisbon in 1980 and became Professor in the Department of Zoology and Anthropology (now Department of Animal Biology) that same year. Soon after the retirement of Germano Sacarrão in 1984, Crespo took over the responsibility of coordinating the teaching and research activities within the newly created group of Development and Evolution.

\section{The transition from research in embryology to research in developmental biology begins}

At this time, José F. David-Ferreira (Fig. 2) was running a flourishing laboratory of cell biology at the Instituto Gulbenkian de Ciência (Gulbenkian Institute of Science), or IGC, in Oeiras, 30 $\mathrm{km}$ from Lisbon (see Carmo-Fonseca and David-Ferreira, 2009). Although David-Ferreira's laboratory was particularly geared towards cell biological and morphological studies, it was in his lab, through the pioneering work of gynaecologist António Pereira Coelho and biologist Christiane Arnout, that in vitro fertilization techniques and embryo transfer were first performed successfully, and resulted, in 1986, in the first "test-tube baby" born in Portugal.

However, José F. David-Ferreira saw the need to also start a line of basic research in the emerging field of developmental biology. During 1985-1986 he accepted three new students (see Fig. 2): Carlos Plancha, an MD from the Faculty of Medicine, Clara Pinto Correia, a biologist from the Faculty of Sciences who had done her undergraduate thesis on amphibians with Eduardo G. Crespo, and Sólveig Thorsteinsdóttir, who had just arrived to
Portugal with a BS degree in Cellular Biology from the University of Kansas, USA, where she worked for a year on pigment cell differentiation in amphibians in the laboratory of Sally K. Frost. David-Ferreira challenged the three to design and develop PhD projects to study the role of the cytoskeleton and the extracellular matrix in early mouse and hamster development. Together they learned the standard morphological and immunohistochemical techniques of the lab and also learned how to obtain, manipulate, culture and ask questions about pre-implantation embryos. However, in spite of their progress and results, it was clear that all would benefit from spending time in laboratories with more Portugal at the time, so all three managed to raise funding and make contacts abroad in order to work for some time in laboratories outside Portugal.

In 1989 Clara Pinto-Correia went to the USA to work in the laboratory of Sabina Sobel at the State University of New York in Buffalo where she completed her PhD work, which she defended at the University of Porto in 1992. She then did a post-doc in the laboratory of James Robl at the University of Massachusets and in 1994 she embarked on a specialization in the area of the history of science at Harvard University. In 1996 she returned to a position as Professor at the Lusófona University in Lisbon. In 1991 Sólveig Thorsteinsdóttir went for the first time to the Hubrecht Laboratory in Utrecht, The Netherlands, and worked in the laboratory of Christine L. Mummery, the beginning of a very fruitful collaboration. In 1989 Sólveig had gotten a teaching assistant position at the Faculty of Sciences where she taught laboratory classes of Animal Physiology and Embryology and Histology under the supervision of Eduardo G. Crespo. With the help of grants from the European Science Foundation and the generosity of Christine Mummery's group, she managed to return to the Netherlands for some time every year while setting up the new techniques she learned in Holland at Crespo's laboratory at the Faculty of Sciences. She finally defended her PhD at the University of Utrecht in 1995. Meanwhile, Carlos Plancha had become a teaching assistant of Embryology and Histology at the Faculty experience in developmental biology than the ones available in 
of Medicine, under the supervision of José F. David-Ferreira. He had also managed to get funding to spend several periods in the lab of David Albertini at Tufts University in Boston, USA and their collaboration and friendship became long-lasting. In 1993, when David-Ferreira moved his lab from the IGC to the Faculty of Medicine, Carlos moved with him and continued his research on oogenesis and preimplantation development there. He also played an important role in progressively modernizing the teaching of Embryology by introducing a section of developmental biology into the Embryology and Histology curriculum. He defended his $\mathrm{PhD}$ at the University of Lisbon in 1996.

\section{The teaching of Developmental Biology as an indepen- dent subject starts at the Faculty of Sciences, Univer- sity of Lisbon}

From the mid-1990's onwards, developmental biology became progressively more visible in Portugal. At this time funding for science was rapidly improving (see de Sousa, 2009). The Fundação para a Ciência e a Tecnologia (Foundation of Science and Technology), or FCT for short, was giving PhD grants and was funding an increasing number of research projects. However, for students to become interested in developmental biology as a field to work in, they had to have heard about it during their studies. Although the curricula of the classical Embryology and Histology courses were progressively modernized in most Universities, they very often did not go beyond the human, or higher vertebrate, model. As the genetic revolution of developmental biology, best exemplified with the discovery of the genes involved in setting up the bodyplan in Drosophila, with all its implications, started to reach the broader scientific community worldwide, Eduardo G. Crespo realized that the field of developmental biology was in great expansion and getting too big to fit in the course of Embryology and Histology. To accommodate this change in the scientific landscape, Crespo created a new course called Developmental Biology in 1994, the first course with that name in Portugal. The course focused on the genetics of development, particularly on the events leading to the establishment of invertebrate and vertebrate body plans. It was initially lectured by him, then progressively also by Sólveig Thorsteinsdóttir, and included laboratory classes where students got the opportunity to see live embryos and to do a variety of experiments. He maintained the
Embryology and Histology course as a separate course, which with the help of a new teaching assistant, Gabriela Rodrigues, covered the morphological, comparative, and, most importantly, evolutionary approach to the subject, while at the same time opening the student's interests for the questions addressed in the Developmental Biology course. In the same year, the Department of Plant Biology also created a new course, Plant Differentiation and Morphogenesis, taught by José Feijó, which took an integrative and functional approach to plant development. Thus, biology students passing through the University of Lisbon started to become aware of the existence of the field of developmental biology and to clearly distinguish it from more classical embryology studies. Furthermore, the solid preparation that many students got in molecular and cell biology (courses traditionally taught by the Plant Biology Department) made them well prepared to absorb the molecular techniques and concepts underlying the rapid advances in the field, while not losing the evolutionary context of animal diversity.

\section{The first Masters programme in Developmental Biol- ogy is created at the Lusófona University}

A couple of years later, namely in 1996, Clara Pinto Correia returned from Harvard University to a position as Professor at the Lusófona University in Lisbon and launched the first post-graduate (later Masters) course in Developmental Biology. She managed to organize a high quality course relying on the few developmental biologists available in Portugal at the time as well as, with the support of the Fundação Luso-Americana para 0 Desenvolvimento (Portuguese-American Foundation for Development), or FLAD, many invited speakers from the USA. During the first years, a big effort was also made to send students abroad during their thesis year. The Lusófona University also organized yearly meetings dedicated to developmental biology (Jornadas de Biologia do Desenvolvimento) from 1996-2000.

\section{Portugal invests in high quality PhD programmes}

In spite of the efforts in teaching made at several universities, as a science, developmental biology still had a problem of critical mass. A bigger push was needed. This push came as a consequence of a visionary and ambitious $\mathrm{PhD}$ programme aimed at the
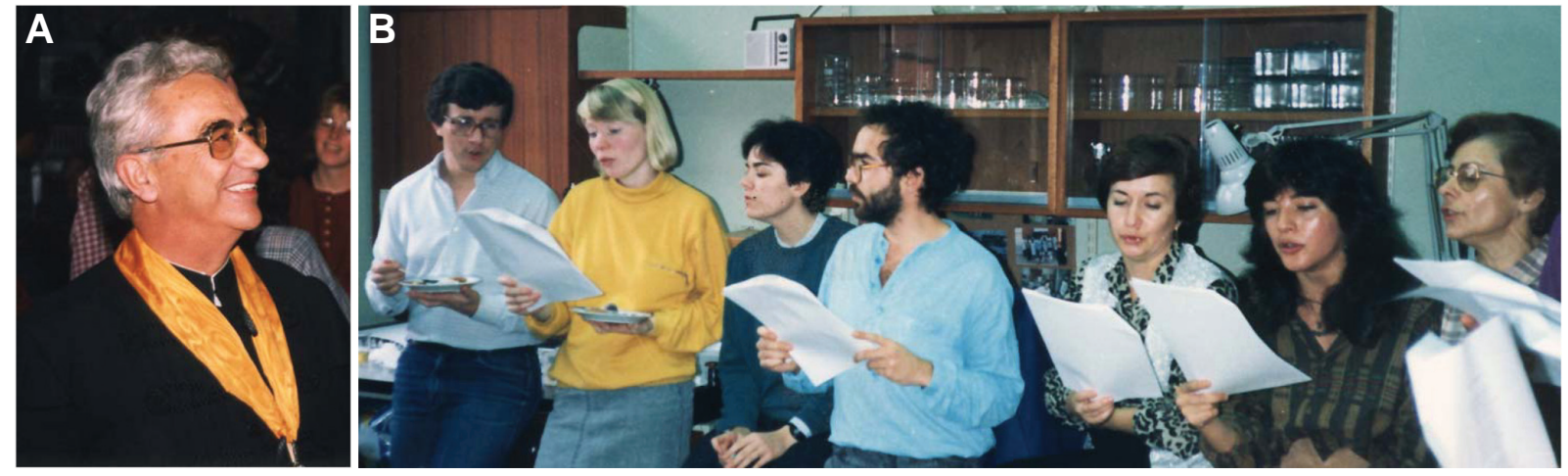

Fig. 2. José F. David-Ferreira. (A) Photo from 1995. (B) Some members of his laboratory at the Instituto Gulbenkian de Ciência, at a Christmas party in 1987. From left to right: António J. Cidadão, Sólveig Thorsteinsdóttir, Rosário Lemos-Cidadão, Carlos Plancha, São Alpiarça, Clara Pinto Correia and Lucinda Mata. 
biomedical sciences in general: Programa Gulbenkian de Doutoramento em Biologia e Medicina (Gulbenkian PhD Programme in Biology and Medicine), or PGDBM, was launched in the academic year 1993/1994 (Fig. 3) by António Coutinho, the director of the IGC and Alexandre Quintanilha, the director of Instituto de Biologia Molecular e Celular (Institute for Molecular and Cellular Biology), or IBMC, affiliated with the University of Porto. Through a partnership between the Calouste Gulbenkian Foundation and FCT (and later on also involving FLAD), this programme set out to choose a group of 15-20 students per year, expose them to a series of intensive courses on a variety of subjects for a school year, lectured by top international speakers, and then send them abroad to laboratories in the field of their choice to work on their PhD projects. Overall, this programme, which ran from 1993 to 1999 had a tremendous impact as it produced around $100 \mathrm{PhD}$ holders, the majority of which returned to Portugal reinforcing the scientific community in a variety of areas, including developmental biology. Other similar PhD programmes soon followed suite: the Programa Graduado em Áreas de

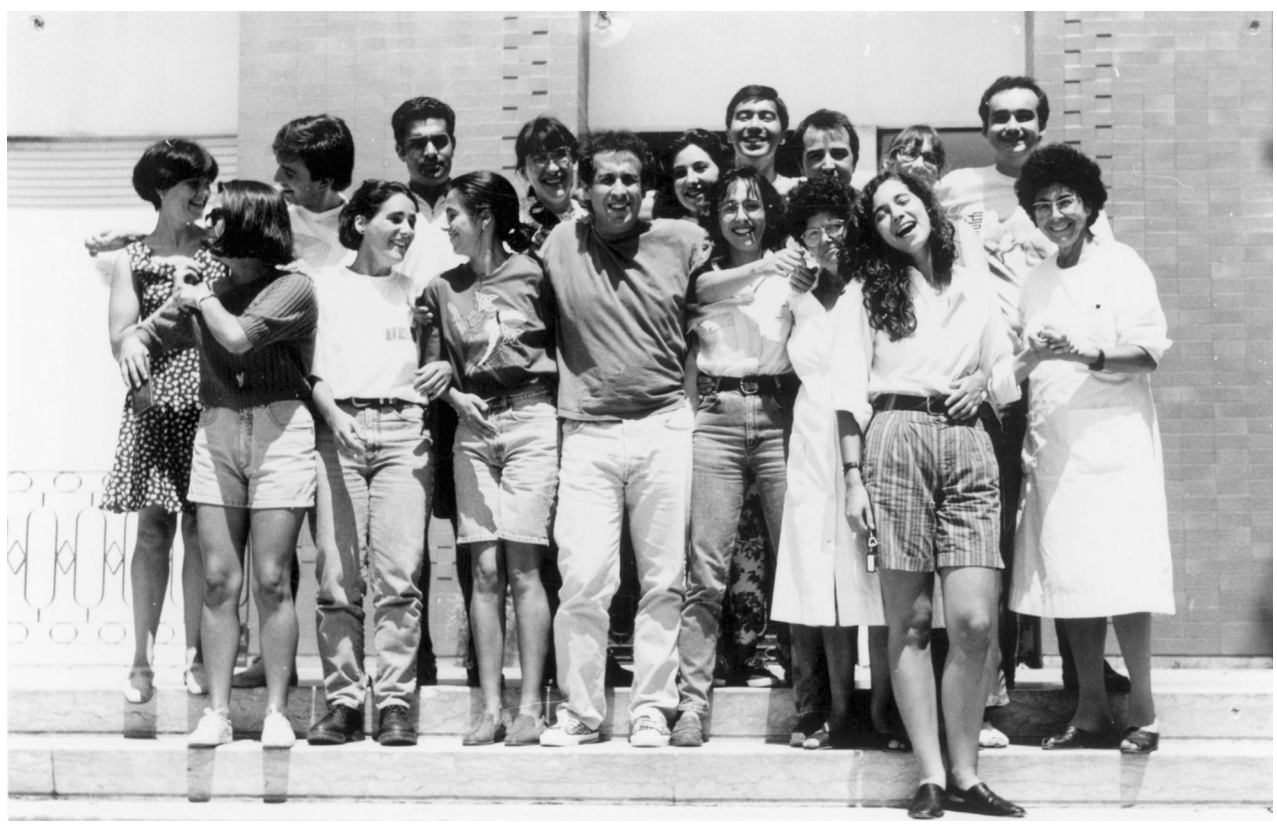

Fig. 3. The first group of the Programa Gulbenkian de Doutoramento em Biologia e Medicina (Gulbenkian PhD Programme in Biology and Medicine) or PGDBM (class of 1993/1994). Back row, from left to right: Isabel Palmeirim, José António Belo, Miguel Castelo Branco, Lia Scotti Campos, Sara Silva, Pedro Pereira, Luís Miguel Martins, Constanze Manso (technician), Miguel Godinho Ferreira. Bottom row, from left to right: Marina Barros Baptista, Margarida Neves, Susana Guedes, António Jacinto, Cristina Costa, Deolinda Sequeira (technician), Paula Duque and Maria José Marinho (course manager). Mário Ramirez and Jorge Vieira were part of the class but are not in the photo. Of this class, Isabel Palmeirim, José António Belo, Lia Scotti Campos, Sara Silva, Sara Guedes and António Jacinto went on to work in developmental biology. Lia Scotti Campos, Sara Silva and Sara Guedes still work abroad.

Biologia Básica e Aplicada (Graduate Programme in Areas of Basic and Applied Biology), GABBA for short, was launched in 1996 by the University of Porto; the successor of the PGDBM, the Programa Gulbenkian de Doutoramento em Biomedicina (Gulbenkian PhD Programme in Biomedicine), PGDB, ran from 2000 to 2004; and Programa de Doutoramento em Biologia Experimental e Biomedicina (PhD programme in Experimental Biology and Biomedicine), PDBEB, affiliated to the University of Coimbra, started in 2002.

\section{Research groups in developmental biology start form- ing}

Towards the end of the 1990's groups doing research in the area of developmental biology were very few. Sólveig Thorsteinsdóttir, who in 1996/1997 had spent a 6-month post-doc in the laboratories of Marylin Duxson and John Harris in Otago, New Zealand to learn about skeletal muscle development, with the support of Eduardo G. Crespo set up a group working on the role of the extracellular matrix during muscle development in the Animal Biology Department at the Faculty of Sciences of the University of Lisbon. Soon after, Gabriela Rodrigues, who had done her PhD on epithelial cell biology with Lucinda Mata from David-Ferreira's group, joined the group. José Feijó and Rui Malhó worked on the role of ion currents and calcium signalling in the development of pollen tubes in the Plant Biology Department at the same University. Carlos Plancha continued his work, now with António J. Cidadão, also from David-Ferreira's group, on mammalian oogenesis at the Faculty of Medicine, and became, together with Mário Sousa from the University of Porto, a pioneer in basic research in reproductive biology, with relevance to medically assisted reproduction. Finally, Domingos Henrique, who left Portugal in 1991 after finishing a PhD in Biochemistry, returned after six years of post-doctoral studies in developmental neurobiology in the laboratories of David Ish-Horowicz and Rosa Beddington. He set up his lab at the Faculty of Medicine at the University of Lisbon in 1997 and started a group devoted to neural development.

However, this scarce landscape was about to change rapidly within only a handful of years. In 1999, José Feijó set up a new group of plant developmental biology at the IGC where he also promoted an international course on plant development (Fig. 4). Later that same year, two former PGDBM students, José António Belo and Isabel Palmeirim returned to set up their labs at the IGC. José António Belo had done his PhD with Edward De Robertis at the Howard Hughes Medical Institute, at the University of Californa in Los Angeles, USA, having being involved in establishment of the role of the anterior visceral endoderm as a signalling centre, and set out to study early gastrulation, head induction and leftright asymmetry. Isabel Palmeirim had contributed to the discovery of the segmentation clock while doing her PhD in the lab of Nicole LeDouarin in Paris under the supervision of Olivier Pourquié. In 1998 she was awarded, together with Domingos Henrique, David Ish-Horowitz and Olivier Pourquié, with the prestigious 
Gulbenkian Prize for Science (Prémio Gulbenkian de Ciência) for the discovery of the segmentation clock and in 1999 she was awarded a medal of honour from the President of Portugal for her achievements. At the IGC she set up a group aimed at studying the temporal control of somitogenesis and limb development. Also in 1999, Sólveig Thorsteinsdóttir's group was accepted as the first external group at the IGC. Domingos Henrique's group soon applied for, and was given, the same status. This novel IGC concept of external groups was to prove very important since it gave investigators from external institutions the opportunity to use the facilities of the IGC and mix with its members, and gave the IGC members the chance to get to know Portuguese scientists that had gone different scientific paths and to get a feeling for how things worked at other institutions. In 2000, António Duarte, who had done a two-year post-doc with Domingos Henrique, set up his own research group on embryonic vascular development at the Veterinary Faculty of the Technical University of Lisbon. Also in 2000, Fernando Casares, who had worked with Ernesto SánchezHerrero and Gines Morata at the Centro de Biología Molecular Severo Ochoa in Madrid and done a post-doc on Drosophila Hox genes and the homothorax transcription factor with Richard Mann at Columbia University, started his own group working on Drosophila development at the IBMC in Porto. He also took over the organization of the Developmental Biology module within the GABBA PhD programme. In 2000, Joaquín Rodríguez-León, a post-doc of Juan Carlos Izpisúa Belmonte (Salk Institute, USA) came to the IGC and, together with Izpisúa Belmonte, organized a group working on limb development. Moisés Mallo, who did a post-doc in the laboratory of Thomas Gridley at Roche, New Jersey, USA, and subsequently ran his own group, focusing on the role of Hox genes in neural crest development, at the MaxPlanck Institute in Freiburg, Germany, for 6 years, arrived in 2001 and set up a group working on Hox genes in neural crest and axial skeletogenesis. Finally, in 2002 António Jacinto, who had worked on the role of hedgehog in patterning the Drosophila wing with Phil Ingham and on morphogenetic movements during dorsal closure and wound healing in Drosophila with Paul Martin, both in London, set up a group dedicated to the study of the control of morphogenetic movements during Drosophila development.

Thus from 1999 to 2002, the number of groups working within the field of developmental biology grew extraordinarily. More importantly, collaborations started between the different groups, and meetings presenting and discussing the work in progress were held regularly. Furthermore, the Embryology and Developmental Biology courses taught at the Faculty of Sciences of the University of Lisbon were producing a considerable number of young biologists with knowledge of, and more importantly, with great enthusiasm for the field. Thus interested students from the Faculty of Sciences streamed into these newly created groups. Meanwhile, in 2003 the Lusófona University set up an under- graduate programme in Biology and created a course on Developmental Biology, so students from there also started to show interest in the field. The cloning of Dolly the sheep in $1997 \mathrm{had}$ also raised a general interest for developmental biology in society. We and others were very much sought after to go to high schools, youth events and student gatherings to decipher the meaning of this breakthrough, and developmental biologists were also frequently contacted by the media. Through these events, aimed at clarifying and explaining the technological advances in the field to the general public, students from a variety of sources became aware of developmental biology as a defined sub-area of Biology and some of these, sooner or later, also channelled into working within the area.

\section{Research groups in developmental biology spread and newcomers keep arriving}

In 1999, José António Belo was hired as a Professor at the University of Algarve in Faro, but he maintained his group at the IGC until 2006, and commuted to Algarve to teach. When his laboratory at the University of Algarve was ready, the whole group moved, and established links with another Professor, Leonor Cancela, already at the university working on osteogenesis in fish. One of his post-docs, Ana Teresa Tavares, stayed at the IGC working on left-right asymmetry and later on vasculogenesis. In 2001, Isabel Palmeirim was hired as Professor in the newly created School of Health Sciences at the University of Minho in Braga. Her group, including her post-doc Leonor Saúde, who had just come back from a PhD in the lab of Derek L. Stemple in London, initially stayed at the IGC and Leonor created her own group in 2004. Meanwhile new members were added to Isabel's

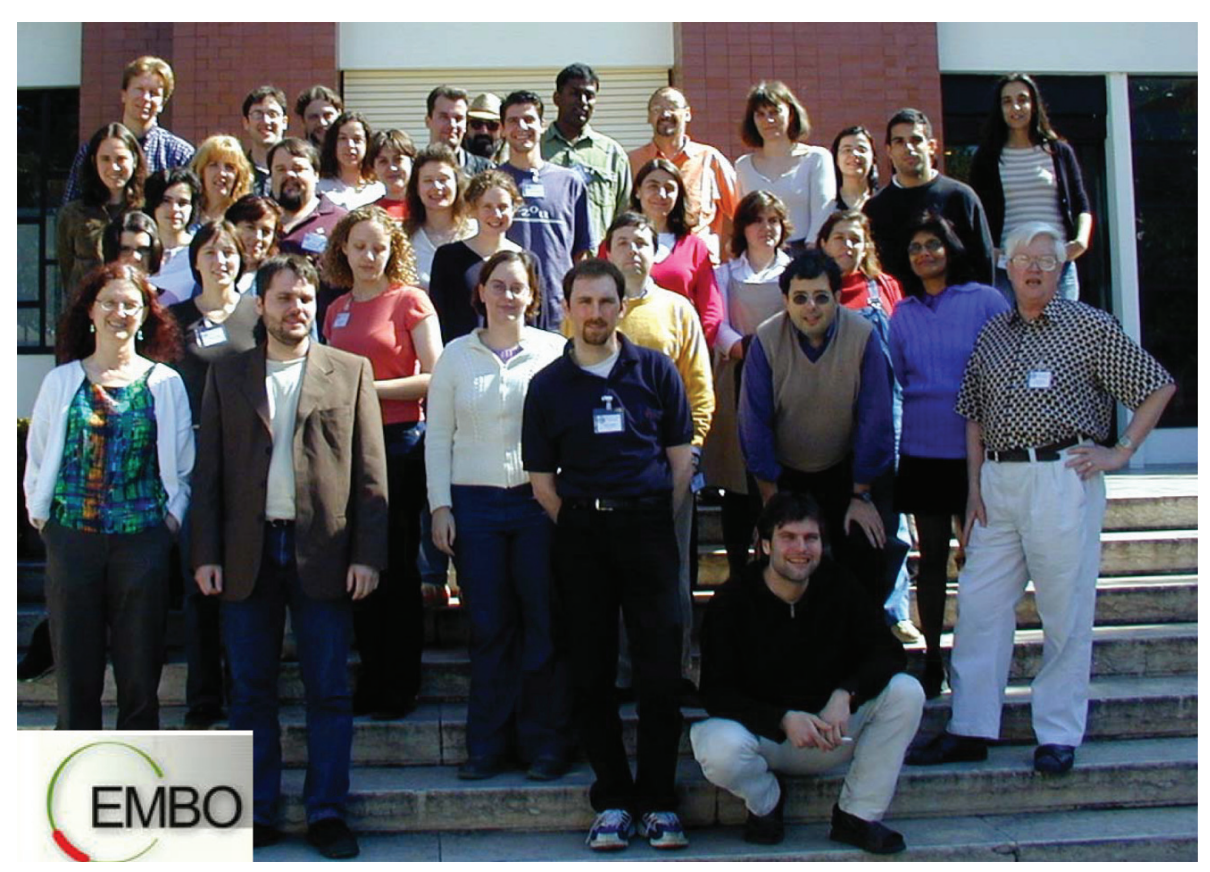

Fig. 4. The participants of the 2002 “Gulbenkian/EMBO Practical Course on Plant Development: the Molecular and Cellular Basis" with some of the invited speakers. This course, organized by José Feijó (in sunglasses on the right), with the secretarial help of Greta Martins (in blue on the right), was held at the Instituto Gulbenkian de Ciência (IGC) yearly from 1996 to 2004 and has been sponsored by EMBO for the last 4 years. 


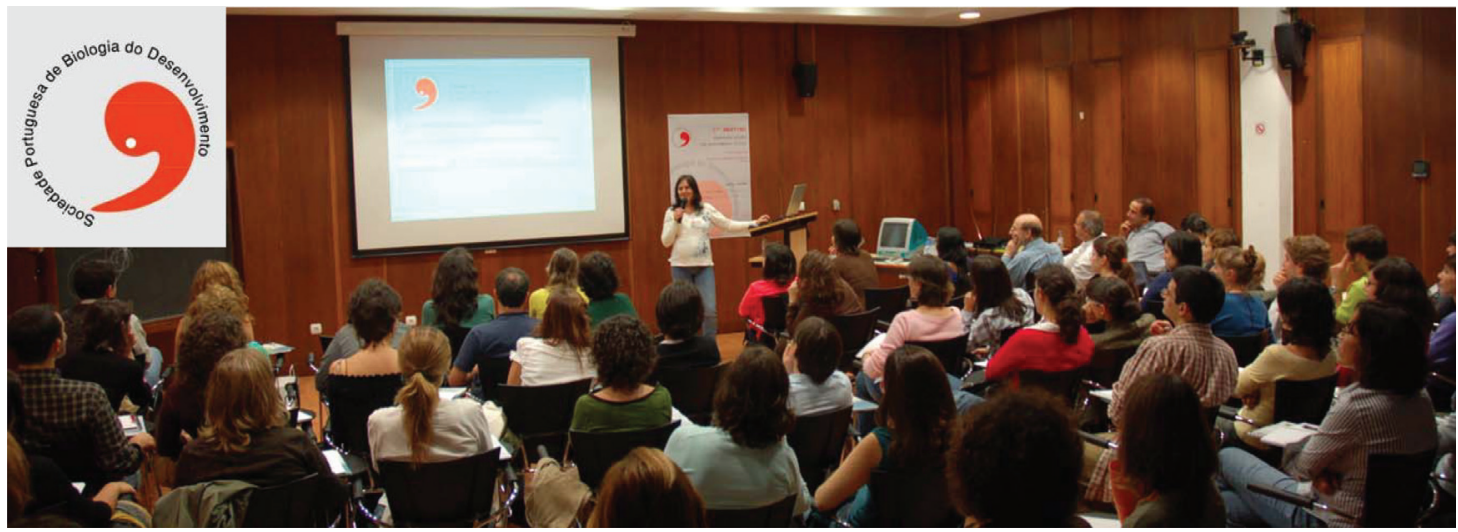

Fig. 5. Isabel Palmeirim, president of the Portuguese Society of Developmental Biology, inaugurates the first scientific meeting of the Society held at the Instituto Gulbenkian de Ciência (IGC) on 27-28 October, 2006.

growing laboratory at the University of Minho and, in 2003, Jorge Correia Pinto was also recruited to the School of Health Sciences and started a group working on lung development and respiratory physiology. In 2003, Fernando Casares moved to the newly created Centro Andaluz de Biologia del Desarrollo in Seville, Spain and started to focus his studies on Drosophilaeye development. Part of his group, including post-doc Paulo Pereira, who started working with Fernando Casares in 2001, has remained at the IBMC, and Paulo has also lectured part-time at the School of Health Sciences, University of Minho in Braga. Furthermore, Fernando Casares has continued to be responsible for the Developmental Biology module of the GABBA PhD programme which has in recent years, much to the students' delight, been held in Seville (see Casares, 2009).

Meanwhile, more former PGDBM students returned after doing their PhDs and post-docs abroad, and set up their groups at the IGC. Élio Sucena came to the IGC in 2003 after a PhD and post-doc on the morphological evolution between closely related species of Drosophilain the lab of David Stern in Cambridge, UK, and Princeton, USA, and post-doc work with Miodrag Grbic in London, Canada. Unlike all other developmental biology groups that had become established in Portugal until then, his group set out to take an evolutionary approach to development and was thus the first modern Evo-Devo group in Portugal. In 2006, Élio Sucena got a position as Professor at the Faculty of Sciences of the University of Lisbon, and played a decisive role in the launching of a Masters in Evolutionary and Developmental Biology there (see below). Rui Martinho, who had done his undergraduate training with José Feijó, did a PhD on cell cycle followed by a Jacinto and Claudio Stern. post-doc on Drosophila development with Ruth Lehmann at the Skirball Institute, USA, arrived at the IGC in 2006. He set up a group focusing on epithelial morphogenesis in early Drosophila development. Finally, Patrícia Beldade set up a group at the IGC in 2007. She worked on the genetic control of color patterns in butterfly wings in the lab of Paul Brakefield at the University of Leiden, and then did a post-doc with Anthony Long in Irvine, USA. At the IGC, Patricia Beldade's group, the second Evo-Devo group in Portugal, focuses on studying the genetic basis of phenotypic variation and adaptive evolution. In 2006, António Jacinto moved his group from the IGC to the newly created Instituto de Medicina Molecular(Institute of Molecular Medicine), or IMM, at the Faculty

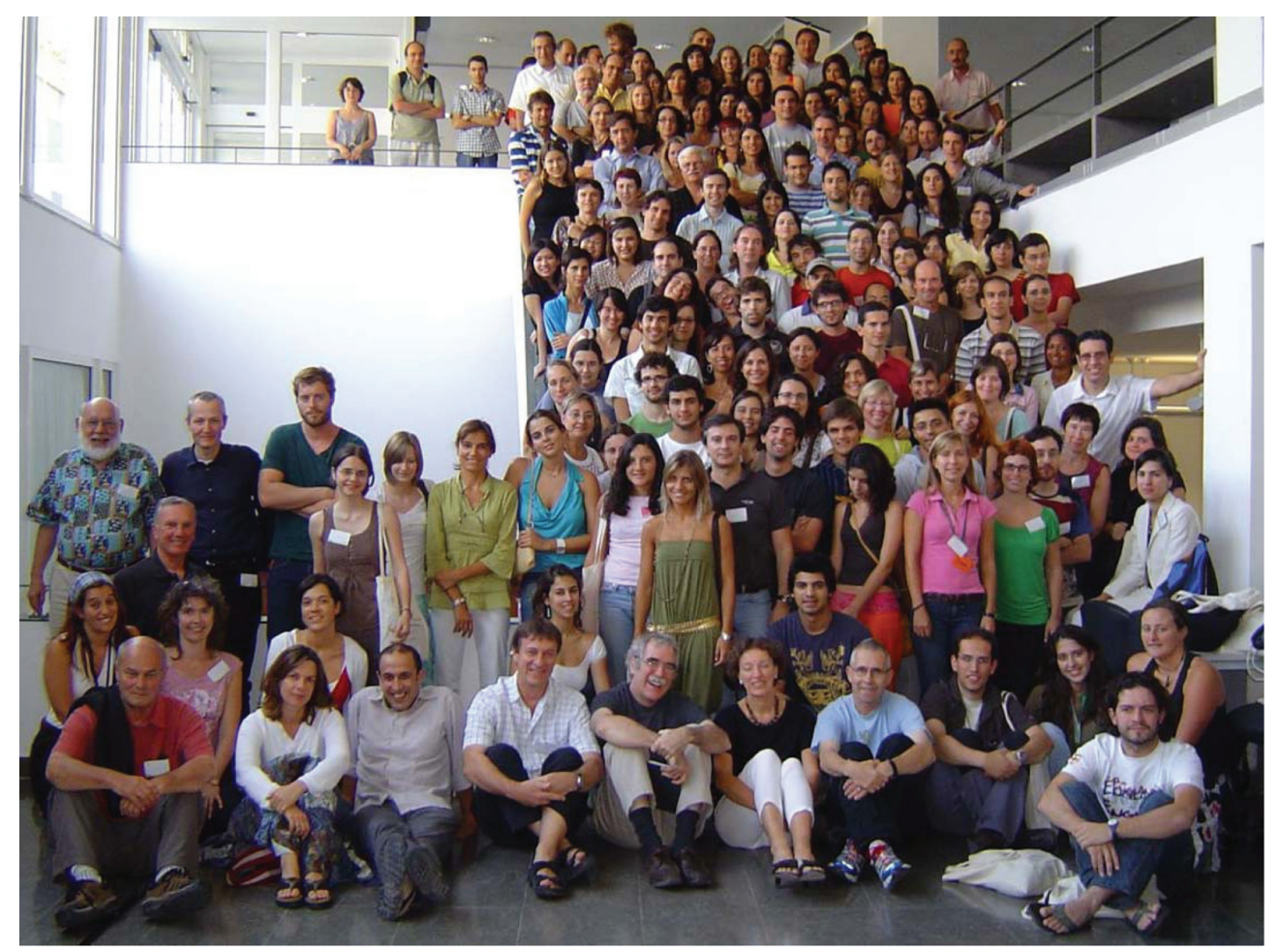

Fig. 6. Participants of the "Cells into Organs" network symposium held at the Institute of Molecular Medicine (IMM) from 31 August to 2 September (2007). The symposium, entitled "Mechanisms of early development: cell fate determination, morphogenesis and patterning", was organized by António 
of Medicine, University of Lisbon. Together with post-doc Nuno Afonso who did his PhD with Martin Catala in Paris, António Jacinto expanded his goals and set out to study regeneration in Drosophila and zebrafish. In 2006, Joaquín Rodríguez-León moved to the newly created Centro de Medicina Regenerativa in Barcelona, but his post-doc Catarina Certal, who had done her $\mathrm{PhD}$ on ion currents in plant development with José Feijó, stayed at the IGC, revisiting the subject of ion currents in vertebrate limb development. In 2008, Leonor Saúde moved her group from the IGC to IMM and presently focuses on the molecular mechanisms that control asymmetric versus symmetric development. Also in 2008, through a new programme launched by the FCT, a number of post-docs working in developmental biology in Portugal and abroad, applied for, and were awarded, five year research positions at a variety of institutions. Thus, one more round of new groups is emerging.

\section{Portuguese developmental biologists form Centres, Societies and integrate European networks}

From 2002 to 2007, the number of groups working in developmental biology increased tremendously, and this increase continues as post-docs in the current groups are successfully applying for new positions and new post-docs come from abroad. Although communication between the different groups has been extensive and mixed labmeetings common, it was time to formalize these interactions.

A first step in this direction was taken when a group of researchers at the IGC, led by Moisés Mallo, proposed to the FCT the formation of the Centro de Biologia do Desenvolvimento (Centre for Developmental Biology), an association between IGC (and later also IMM) research groups working in development and closely related fields. This Centre was formally recognized by the FCT in 2004 and started its activites with funding from the FCT that same year.

A second important step was the creation of the Sociedade Portuguesa de Biologia do Desenvolvimento (Portuguese Society of Developmental Biology), or SPBD, in 2006. Isabel Palmeirim was elected the first president and the first scientific meeting was held in October 2006 (Fig. 5; Andrade and Saúde, 2007; see Palmeirim and Aréchaga, 2009). In addition to organizing scientific congresses and workshops, the SPBD also organizes the Embryo Club, a monthly meeting featuring presentations by post-docs, PhD or Masters students which normally rotates between the IMM, the Faculty of Sciences of the University of Lisbon and the IGC, but Embryo Clubs have also been held at the Universities of Algarve and Minho. This event, which is enthusiastically promoted by its organizers, Nuno Afonso, Gabriel G. Martins, and Susana Lopes, gives everybody working in developmental biology the chance to meet everybody else, and has been instrumental in maintaining and even increasing the cohesiveness of the developmental biology community in Portugal. ment".
Meanwhile, some Portuguese developmental biologists started getting involved in the nascent field of Stem Cell research and, while maintaining their activities related to developmental biology, initiated projects in the promising field of stem cell biology. Thus the Sociedade Portuguesa de Células Estaminais e Terapia Celular (Portuguese Society of Stem Cells and Cell Therapy) was founded in 2004. This society has put together not only developmental biologists interested in the field of stem cell research, but also cell biologists, immunologists, neurologists, cancer researchers and clinicians. The SPCETC has been an active voice in society since its creation.

Another important development during this period was the incorporation of several groups into European activities. Domingos Henrique's group is part of the European Project "FunGenES" (Functional genomics in engineered ES cells) (FP6; 2004-2009) and the groups of António Jacinto, Isabel Palmeirim, Joaquín Rodríguez-León and Sólveig Thorsteinsdóttir integrate the European Network of Excellence "Cells into Organs" (FP6; 20042009). Several activities of the "Cells into Organs" network have taken place in Portugal. For example, there has been an annual meeting (2005) and a post-graduate course (2005) at the University of Minho and two international symposia (2007 and 2009) in Lisbon (Fig. 6).

\section{Research in developmental biology again benefits teaching}

All this increased activity has benefited the teaching of developmental biology tremendously at all levels. Developmental Biology courses have been created at several Universities and at others the curricula of existing courses have been enriched with Developmental Biology modules. For example, under the coordination of Leonor Parreira, the Embryology and Histology course at the Faculty of Medicine, University of Lisbon, has come to dedicate a significant section, lectured by Moisés Mallo, Carlos Plancha and others, to Developmental Biology. Another example is a module of Developmental Biology, organized by Fernando

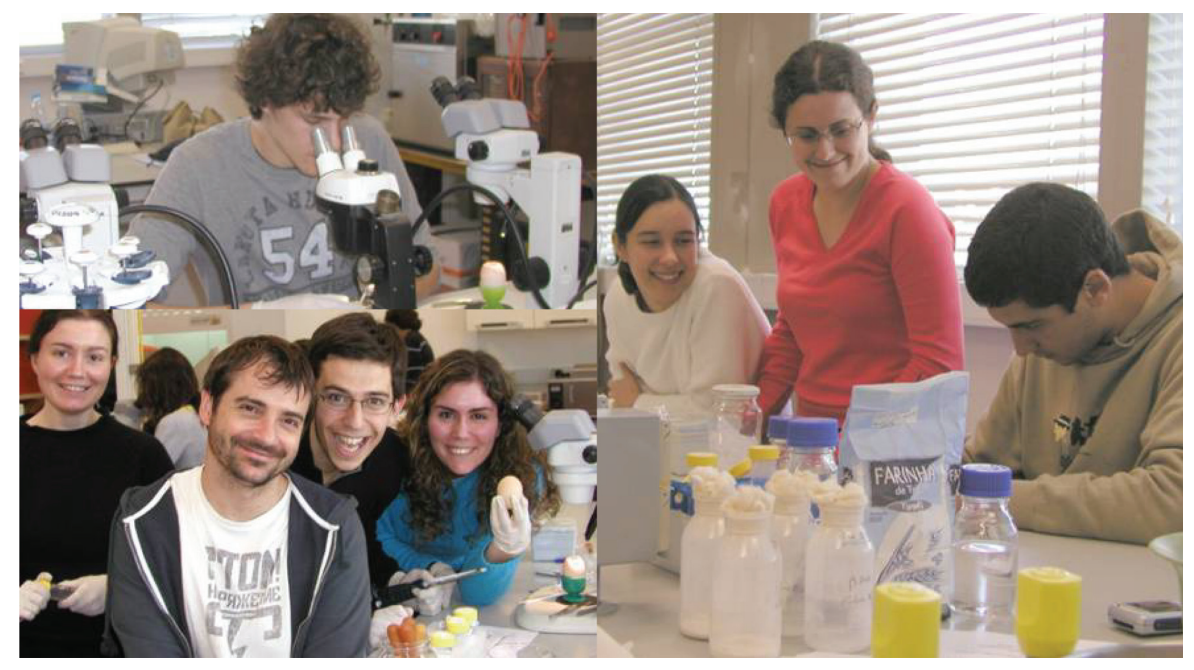

Fig. 7. Students of the Masters in Evolutionary and Developmental Biology at the Faculty of Sciences, University of Lisbon (class of 2007/2008), working on their laboratory projects within the courses "Genes and Molecules in Development" and "Evolution and Develop- 
Casares and Paulo Pereira, which forms part of a Molecular Biology course lectured to Biochemistry students at the University of Porto. Furthermore, modules addressing development continue in several PhD programmes. Most if not all institutions have Open Days for the public, and visits from high schools, where the participants get a glimpse of what scientists do, and developmental biology groups have been taking an active part in these initiatives.

From our personal perspective, we can say that our teaching has benefited extraordinarily by this boom in activity. Starting in 2005 , our Faculty of Sciences entered the process of restructuring its undergraduate and graduate teaching in order to integrate the Bologna process. This gave us and our colleagues working in evolution the opportunity to create a new third year specialization in the area of Evolutionary and Developmental Biology in our undergraduate Biology programme, which started in 2006. Furthermore, in 2007 we started a new Masters in Evolutionary and Developmental Biology (Fig. 7), which is organized in modules of intensive courses. As co-coordinator of this Masters together with Manuela Coelho and Maria João Collares-Pereira, both evolutionary biologists, Élio Sucena has managed to link the two areas covered by the programme. Thus apart from having core courses in evolution and development, this Masters also has courses aimed at integrating the two fields (such as the Evolution and Development course, taught by Élio Sucena) and to point the students into emerging directions (such as the Stem Cell Biology and Technology course, taught by Gabriela Rodrigues, and the Bioimaging course, taught by Gabriel G. Martins). Gabriel G. Martins, a recent addition to the team, started his career in developmental biology by entering the Masters in Developmental Biology at the Lusófona University the year it opened (1996), did his Masters and PhD thesis in the USA and came back to Portugal

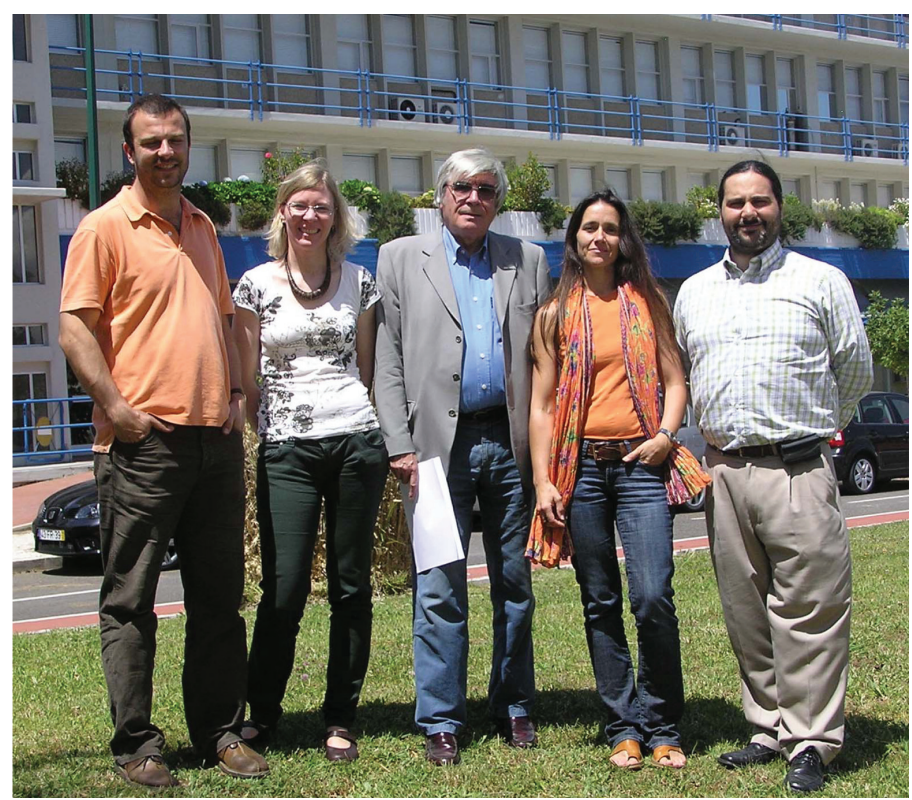

Fig. 8. Current "in-house" staff responsible for the coordination and teaching of Developmental Biology within the Masters in Evolutionary and Developmental Biology in front of the Biology building of the Faculty of Sciences, University of Lisbon. From left to right: Élio Sucena, Sólveig Thorsteinsdóttir, Eduardo G. Crespo, Gabriela Rodrigues and Gabriel G. Martins. in 2004 as a post-doc with Sólveig Thorsteinsdóttir and Isabel Palmeirim. He got awarded a five-year research position at the Faculty of Sciences in 2008.

It should be stressed that, in addition to this "in-house" staff (Fig. 8), this Masters programme has been able to rely on the goodwill and enthusiasm of a great number of colleagues within developmental biology and related fields (for example from stem cell biology, cell biology and immunology) who have given lectures, brought their working material and expertise, set up experiments for the students to perform, and opened up their laboratories for them.

\section{Concluding remarks}

Developmental biology has come a long way in Portugal in just a little bit more than a decade. Since the first Developmental Biology course was created in 1994, the field has mushroomed up at many Universities and is a subject included in most PhD programmes in Biology and Biomedical sciences. Research groups went from only a handful of under-funded groups to over 20 groups (with numbers still rising) from north to south, capable of raising research funding and all making a dedicated effort to do good quality science. Although several people played key roles for this to happen, as extensively described in this article, the feeling we get, looking back at it all, is that success came through an earnest collective effort: a desire of everyone involved to advance and spread developmental biology in Portugal. The problem of critical mass, so evident only 10 years ago, has been overcome. So where should we aim now? It would be nice if, in 10 years from now, people would think of Portugal as a country where there is a good school of developmental biology. Striving to teach well, collaborate and to do good science is the best way to earn that distinction. In fact, the rise of developmental biology in Portugal demonstrates that, with vision, enthusiasm and joint efforts, one can go a long way.

\section{Acknowledgements}

We are indebted to Juan Aréchaga for giving us the opportunity to write this article. We thank Élio Sucena, Isabel Palmeirim, Moisés Mallo, José António Belo, José Feijó, Joaquín Rodríguez-León, Leonor Saúde, Catarina Certal, Fernando Casares, Paulo Pereira, António Duarte, Antonio Jacinto, Gabriel G. Martins, Ana Teresa Tavares, Fernanda Bajanca and Pedro Rifes for their comments and corrections on the manuscript and Lucinda Mata, Paula Duque, António Jacinto and Leonor Saúde for photographs. In order to simplify the account, in this paper we only mention individuals and groups that work on core developmental biology problems. Thus we apologize for not including the great number of colleagues that work on problems of cell biology, molecular biology, stem cell biology, reproductive biology, evolution, neurobiology, immunology, hematopoiesis etc. with direct or indirect applications to development. We also apologize to anyone working in developmental biology that we might, inadvertedly, not have mentioned. Last, but not least, we thank our students for their interest, enthusiasm and challenging questions.

\section{References}

ANDRADE, R.P. and SAÚDE, L. (2007). First meeting of the Portuguese Society for Developmental Biology (SPBD). Int. J. Dev. Biol. 51: 177-181.

CASARES F. (2009). Iberia: from fable to the bench. Int. J. Dev. Biol. 53: 12691271.

CARMO-FONSECA, M. and DAVID-FERREIRA, J.F. (2009). Idealism and roman- 
tic patriotism for science - an interview with José Francisco David-Ferreira. Int. J. Dev. Biol. 53: 1273-1275 (doi: 10.1387/ijdb.072314mc).

DAVID-FERREIRA, J.F. (2009). Augusto Celestino da Costa (1884-1956) professor, scientist and science promoter. Int. J. Dev. Biol. 53: 1161-1164 (doi: 10.1387/ijdb.072313jd).
DE SOUSA, M. (2009). A personal account of the development of modern biological research in Portugal Int. J. Dev. Biol. 53: 1253-1259 (doi: 10.1387/ijdb.072278md)

PALMEIRIM I. and ARÉCHAGA J. (2009). A small great history of the sister Societies of Developmental Biology in Spain and Portugal. Int. J. Dev. Biol. 53: 1261-1268 (doi: 10.1387/ijdb.082714ip)

\section{Further Related Reading, published previously in the Int. J. Dev. Biol.}

See our recent Special Issue Epigenetics \& Development edited by Saadi Khochbin and Stefan Nonchev at:

http://www.ijdb.ehu.es/web/contents.php?vol=53\&issue=2-3

See Special Issue Pattern Formation edited by Michael K. Richardson and Cheng-Ming Chuong at:

http://www.ijdb.ehu.es/web/contents.php?vol=53\&issue=5-6

Iberia: from fable to the bench

Fernando Casares

Int. J. Dev. Biol. (2009) 53: 1269-1271 (doi: 10.1387/ijdb.072461fc)

Idealism and romantic patriotism for science - an interview with José Francisco DavidFerreira

Maria Carmo-Fonseca and José Francisco David-Ferreira

Int. J. Dev. Biol. (2009) 53: 1273-1275 (doi: 10.1387/ijdb.072314mc)

Augusto Celestino da Costa (1884-1956) - professor, scientist and science promoter José-Francisco David-Ferreira

Int. J. Dev. Biol. (2009) 53: 1161-1164 (doi: 10.1387/ijdb.072313jd)

Portuguese contributions to the discovery and characterization of the embryonic molecular clock

Susana Pascoal and Isabel Palmeirim

Int. J. Dev. Biol. (2009) 53: 1421-1425. (doi: 10.1387/ijdb.072285sp)

A personal account of the development of modern biological research in Portugal Maria de Sousa

Int. J. Dev. Biol. (2009) 53: 1253-1259. (doi: 10.1387/ijdb.072278md)

First Meeting of the Portuguese Society for Developmental Biology (SPBD)

Raquel P. Andrade and Leonor Saúde

Int. J. Dev. Biol. (2007) 51: 177-182

Four decades of teaching developmental biology in Germany.

Horst Grunz

Int. J. Dev. Biol. (2003) 47: 193-201

Developmental biology in Ecuador: a 30-year teaching experience.

Eugenia M del Pino

Int. J. Dev. Biol. (2003) 47: 189-192

Research and the teaching of developmental biology in Belgium.

$P$ Van Gansen

Int. J. Dev. Biol. (1992) 36: 5-7

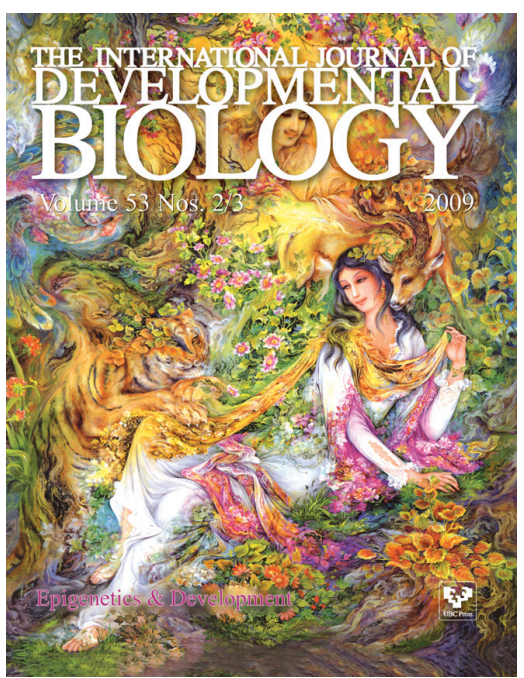

5 yr ISI Impact Factor $(2008)=3.271$

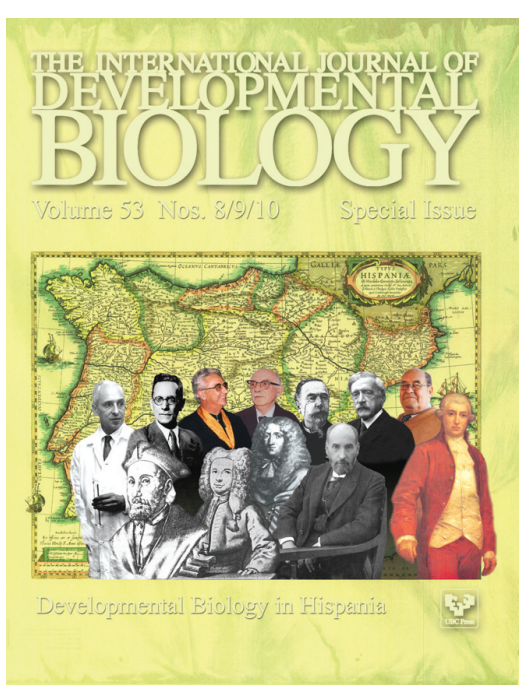

